\title{
MORPHOLOGICAL AND ANATOMICAL FEATURES OF FLAMMULINA FESTIVA SCOTT, 1970 (STYLOMMATOPHORA; CHAROPIDAE) FROM SOUTHERN CHILE, WITH NOTES ON ITS NATURAL HISTORY
}

\author{
CARACTERISTICAS ANATOMICAS Y MORFOLOGICAS DE FLAMMULINA \\ FESTIVA SCOTT, 1970 (STYLOMMATOPHORA; CHAROPIDAE) DEL SUR DE \\ CHILE, CON NOTAS SOBRE SU HISTORIA NATURAL
}

\author{
Francisco J. Cádiz \& Carlos S. Gallardo \\ Instituto de Zoología “Ernst F. Kilian”, Facultad de Ciencias, Universidad Austral de Chile, Casilla 567, Valdivia, \\ Chile.cgallard@uach.cl
}

\begin{abstract}
Flammulina festiva Scott, 1970 is a terrestrial gastropod endemic to southern Chile. Characteristics of living specimens, including the anatomy of the excretory and reproductive systems of this species are here reported for the first time. The excretory system of this species is of the charopid type with a short, curved primary ureter, and a secondary ureter which extends to the excretory sinus. The reproductive system exhibits characteristics similar to other Charopidae. There is an ovotestis that is divided into seven lobes, a well-developed albumin gland, an ovospermial duct with a proximally diverticulate, distally undivided prostatic gland, plus a short oviduct. The terminal portion of the system shows a pointed epiphallus, and a phallus within a phallus sheath. Direct observations in the field suggested this species was active during the day, mainly under decomposing logs, fallen leaves, and under dense, ground-level vegetation in this humid biogeographic zone.
\end{abstract}

KeYwords: Flammulina festiva, Gastropoda, excretory system, reproductive system, Charopidae, Chile.

\section{RESUMEN}

Flammulina festiva Scott, 1970 es gastrópodo terrestre endémico del sur de Chile. Las particularidades morfológicas de las partes blandas de estos caracoles, así como las condiciones bióticas de los lugares en los cuales esta especie se desenvuelve aún son desconocidas. Características de individuos de esta especie, incluyendo la anatomía de los sistemas excretor y reproductor, son reportadas aquí por primera vez. El sistema excretor de esta especie es el de un Charopidae típico, presentando un uréter primario corto y curvado y un uréter secundario que se extiende hasta el seno excretor. El sistema reproductor exhibe características muy similares a las de otros Charopidae. Presenta ovariotestis dividido en 7 lóbulos, glándula del albumen bien desarrollada, espermioviducto con una glándula prostática proximal diverticulada y con la distal indivisa; oviducto corto, con la parte terminal del sistema exhibiendo un epifalo aguzado y falo propiamente dicho (campana) envuelto por la vaina faliana. Observaciones directas en terreno pusieron en evidencia una marcada tendencia de estos animales a estar activos durante el día, principalmente bajo troncos en descomposición, hojas caídas y entre la densa vegetación que compone el sotobosque de esta húmeda zona biogeográfica.

Palabras Claves: Flammulina festiva, Gastropoda, sistema excretor, sistema reproductivo, Charopidae, Chile. 


\section{INTRODUCTION}

Flammulina festiva Scott, 1970 (Fig. 1) is a terrestrial gastropod endemic to southern Chile. It had previously been reported only from near the town of Fresia (X Region) by Scott (1970), for which we had supposed it to be restricted to Valdivian forests (Kuschel 1960) of the coastal region. Nevertheless, the morphological characteristics which best describe this species are still far from adequately established, since the original description of the species was based on only a single shell. There was no original information given on the soft parts, and no details were given on the internal anatomy of the specimen (Scott 1970). The species is the only Chilean representative of the genus Flammulina Martens (1873) (Charopidae); although curiously, it was not included in recent inventories of Chilean species (Stuardo \& Vega 1985, Valdovinos 1999).

Characteristics of living specimens and of the sites where it normally occurs, including the anatomy of the excretory and reproductive systems of this species are here reported for the first time. Knowledge of the internal anatomy of the Chilean terrestrial molluscs, particularly of the microgastropods, is of interest in determining their as yet unstudied phylogenetic and evolutionary relationships.

\section{MATERIALS AND METHODS}

The snails studied were collected during September 2005 in the Arboretum of the Universidad Austral de Chile, which is a semi-urban remnant of native forest near the city of Valdivia (39 $48^{\circ} \mathrm{S}$; $\left.73^{\circ} 14^{\prime} \mathrm{W}\right)$, and in the Reserva Costera Valdiviana ( $39^{\circ} 57^{\prime} \mathrm{S} ; 7^{\circ} 34^{\prime} \mathrm{W}$ ). The snails were returned for observation to the Laboratorio de Malacología of the Instituto de Zoología at the Universidad Austral de Chile, Valdivia, where they were fixed, dissected, and identified. The small sizes of the specimens required they be dissected with the use of a stereoscopic microscope. Measurements of lengths of organs and systems were made using a Wild-Herbrugg stereoscopic microscope fitted with an ocular micrometer. The measurement data were expressed as mean values observed on 22 specimens. Mature adults were those showing a notably swollen seminal vesicle which indicated storage of spermatozoa (Duncan 1975). For better specification, the sizes of each organ were also expressed in relation to the sizes of adjacent organs and with the size of the entire system under study. Drawings were made using the drawing tube accessory of the stereoscopic microscope. Individuals of $F$. festiva studied are deposited in the Malacological Collection of the Zoological Institute of the Universidad Austral de Chile at Valdivia (IZUA Mg2 - 1).

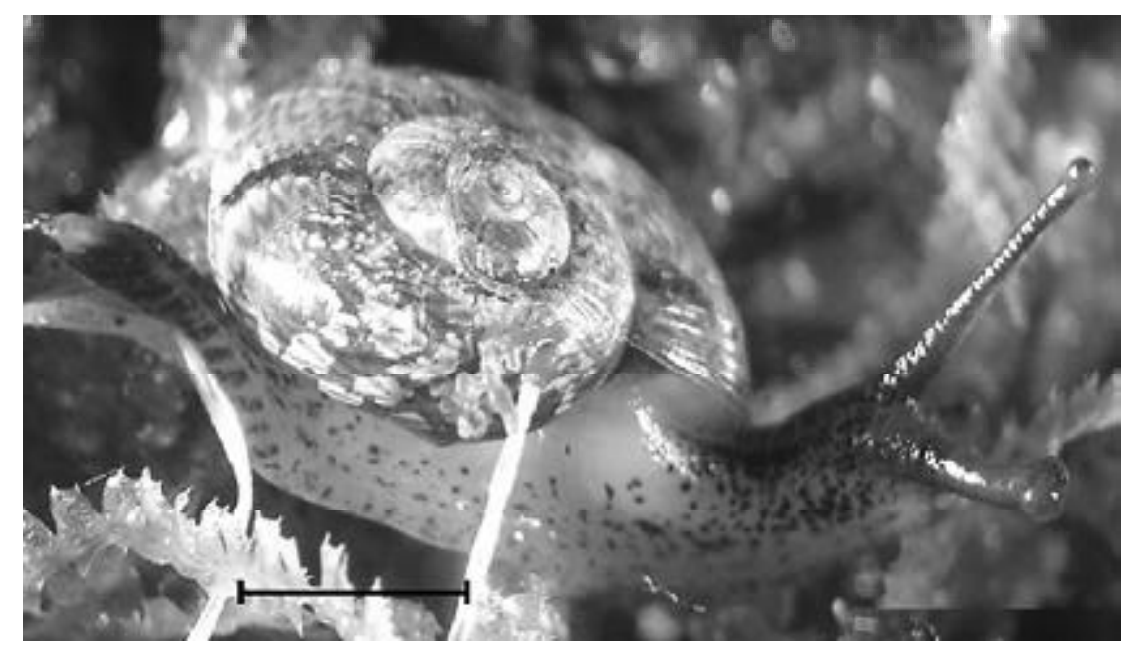

FIgURE 1. Flammulina festiva. Adult specimen. Scale: $5 \mathrm{~mm}$.

FIgURA 1. Flammulina festiva. Especimen adulto. Escala: $5 \mathrm{~mm}$. 
RESULTS

\section{FieLdNotes}

Flammulina festiva is an endemic snail to the native coastal forests at southern Chile, including areas of this vegetational type partially disturbed by human activity. The shells of recently collected specimens generally agreed with the ornamentation patterns originally described by Scott (1970). Adultindividuals measured in the present study had maximum shell diameters (Solem 1976) of 10 to $15 \mathrm{~mm}$ (Figure 2). The body of the snail is cream colored, with irregular, discontinuous, black pigmented blotches on its dorsum. Black pigment is concentrated near the cephalic region, to the bases of the tentacles. A second area of black pigmentation occurs at the end of the foot (Fig.1).
Direct observations in the field have revealed a marked tendency of this species to be active during the day. The snails were found under bark fragments, fallen leaves, humus, and dense vegetation, all of which were wet. The snails prefer to occupy a soil surface normally covered by dense vegetation of the native forest understory. The vegetational community forming the lowest understory of this forest includes Leptostigma arnottianum (Rubiaceae), the introduced ivy Hedera helix (Araliaceae), bryophyte species like the club moss Brachytechium sp., the fern Blechnum hastatum (Blechnaceae), and the creeper Cissus striata (Ampelidaceae) among others. This environment is generally shared with other gastropods such as Stephadiscus mirabilis (Scott 1969), Phyllocaulis gayi (Fischer 1871),Plectostylus sp. and Austrodiscus sp., all of which are endemic pulmonates of this area.
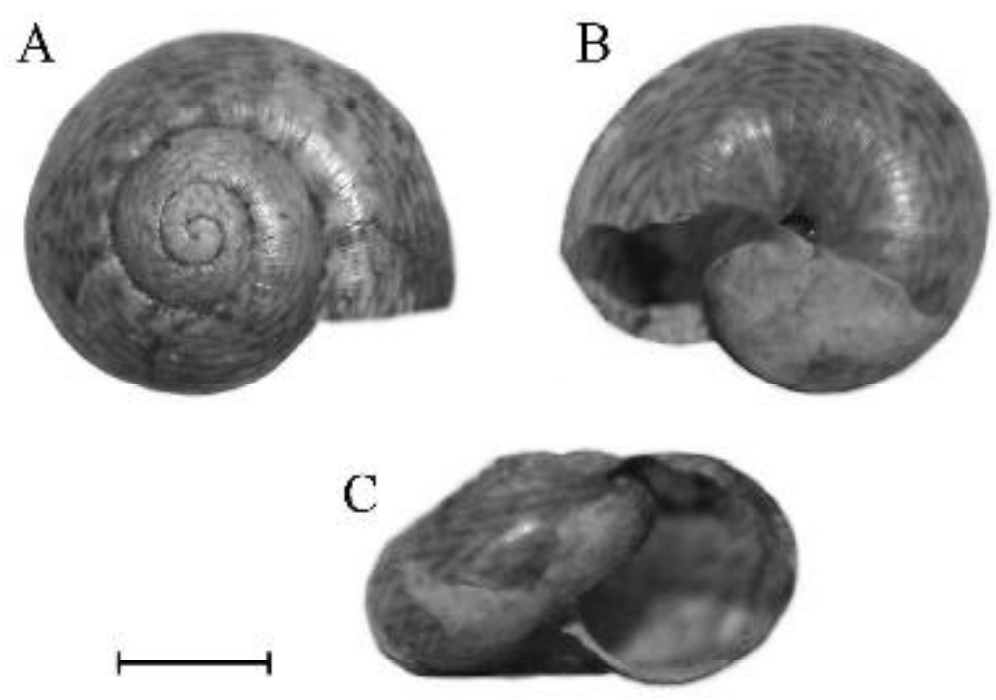

Figure 2. Shell of Flammulina festiva. A: apical view, B: ventral view, C: apertural view. Scale: $3 \mathrm{~mm}$.

Figura 2. Concha de Flammulina festiva. A: vista apical, B: vista ventral, C: vista apertural. Escala: 3 mm.

\section{EXCRETORY SYSTEM}

Figure 3 illustrates the excretory system of $F$. festiva. The kidney is irregularly triangular. It is slightly wider $(3.27 \mathrm{~mm})$ than its height $(3.10 \mathrm{~mm})$, and is about $1 / 3$ the size of the pallial cavity. It is situated in an extreme posterior position within this cavity, with the rectum on its right side and the pericardium on the left, markedly anterior to the final portion of the posterior intestine and the albumin gland. It is thin-walled, yellowish in color, and is semitransparent. The proximal region shows deeper folding than the distal region, giving it a granular appearance. On the side proximal to the lung, it has a right-side concavity, 
into which enters the primary ureter, whose proximal fold is partly covered by the kidney wall. The distal apex of the kidney is positioned on the left side, being strongly curved to the right. Inserted into the internal portion of this fold is the truncated initial part of the primary ureter, where a weak septum occurs which forms the renal pore. The left side is slightly curved, where it inserts into the pericardium. Medially, at this same site, exists a small pore which forms the reno-pericardial duct. The primary ureter is inserted into the right side, in the distal-urethral stage of the kidney. It is very short $(2.65 \mathrm{~mm})$, representing little more than $1 / 3$ of the secondary ureter, and less than half its diameter $(0.22$ $\mathrm{mm})$. It is whitish and semitransparent. Its truncated distal stage is inserted into the brusque curve of the kidney apex, forming a very small septum representing the renal pore. The distal portion of the primary ureter is perpendicular to the secondary ureter. It has a distal curvature forming a poorly defined " $S$ ". It is truncated and slightly dilated distally, continuing to the secondary ureter. The secondary ureter is relatively long (average $=7.56 \mathrm{~mm}$ ), equal to about $8 / 9$ of the total length of the pallial cavity; the proximal portion, $0.34 \mathrm{~mm}$ in average diameter, is somewhat thinner than the distal portion, whose diameter is $0.56 \mathrm{~mm}$. It has the same texture and tonality as the primary ureter. It extends in a position across the left level of the rectum towards the mantle collar where it opens through urethral pore, into the excretory sinus.

The excretory sinus is wide, shallow, and well defined. It is partially covered by a fold of the mantle close to the extreme (anal) portion of the rectum, as a continuation of the urethral pore. The excretory opening is wide, and found adjacent to the opening of the pneumostome, inconspicuously bordered by the mantle edge.

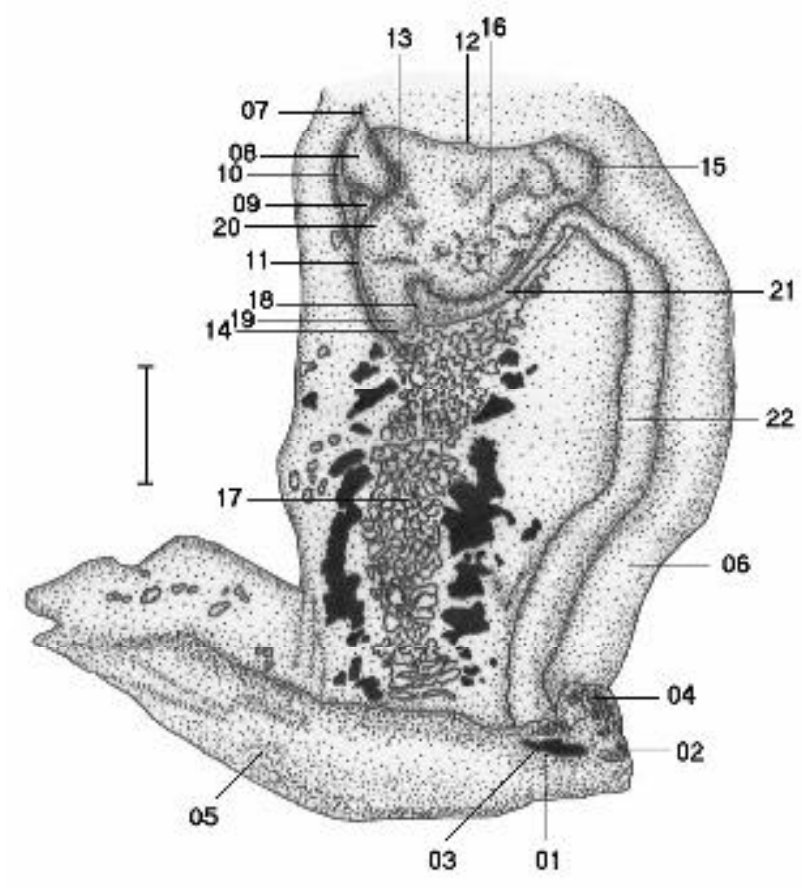

FIGURE 3. Pallial mantle with excretory system of Flammulina festiva. 01: excretory aperture, 02: anus, 03: urethral pore, 04: sheath of excretory aperture, 05: mantle collar, 06: rectum, 07: aortic artery, 08: ventricle, 09: auricle, 10: pericardium, 11: pulmonary vein, 12: intestinal level of kidney, 13: pericardial level of kidney, 14: pulmonary level of kidney, 15: rectal level of kidney, 16: urethral level of kidney, 17: pulmonary mantle, 18: renal papilla, 19: renal apex, 20: renal-pericardial duct, 21: primary ureter, 22: secondary ureter. Scale: $2 \mathrm{~mm}$.

FIGURA 3. Manto paleal con el sistema excretor de Flammulina festiva. 01: apertura excretora, 02: ano, 03: poro uretral, 04: cubierta de la apertura excretora, 05: collar del manto, 06: recto, 07: arteria aorta, 08: ventrículo, 09: aurícula, 10: pericardio, 11: vena pulmonar, 12: porción intestinal del riñón, 13: porción pericardial del riñón, 14: porción pulmonar del riñón, 15: porción rectal del riñón, 16: porción uretral del riñón, 17: manto pulmonar, 18: papila renal, 19: ápice renal, 20: ducto renopericardial, 21: ureter primario, 22: ureter secundario. Escala: $2 \mathrm{~mm}$. 


\section{REPRODUCTIVE SYSTEM}

Figure 4 presents the structure of the reproductive system. The ovotestis is divided into seven lobules, each decreasing in size from distal to apical. The lobules are composed of diminutive, poorly differentiated acini. Their color is whitish to slightly yellowish, contrasting with the brown color of the digestive gland. The sizes of the lobules range from $1.33 \mathrm{~mm}$ in the extreme distal region to $0.86 \mathrm{~mm}$ in the apical region. A small vas efferens arises from each lobule to join the ovospermial duct. The distal vas efferens from the last lobule is somewhat larger than the one arising from the first lobule.

The ovospermial duct emerges from the vas efferens of the last lobule, in the middle of the first half of the posterior digestive gland. It has a proximal portion of the same diameter as the vas efferens $(0.16 \mathrm{~mm})$, with the distal portion enlarging to give space to the seminal vesicle. The seminal vesicle is whitishiridescent in color, and is $3.46 \mathrm{~mm}$ in length, which is equivalent to $1 / 4$ the length of the entire reproductive system. It is completely corrugated. In its distal portion, following the seminal vesicle, there is a short filament $0.79 \mathrm{~mm}$ in length which enters the albumin gland through the fertilization complex. This segment is very small, representing somewhat less than $1 / 4$ of the entire length of the duct.

The seminal vesicle appears as a gradual dilation of the mid-portion of the ovulospermial duct which gives rise to the seminal vesicle. This is more dilated in its mid-portion, between the vas efferens and the fertilization complex. It has about $65 \%$ of the extension of the ovospermial duct ( $2.28 \mathrm{~mm}$ in length) and is almost three times its diameter $(0.47 \mathrm{~mm})$. Similar to the duct, it is whitish-iridescent, but with a somewhat yellowish tone. The vesicle is attached to the fertilization complex by a distal portion of the ovospermial duct.

The fertilization complex is positioned on the ventral side of the albumin gland. It is a small sac-shaped diverticulum partially embedded in the albumin gland. Its proximal portion terminates in a small, blind sac. The mid-distal part is associated with the acini of the albumin gland and to the ovospermial duct, and extends distally to the ovospermial duct.

The albumin gland is positioned partially below the kidney, between the anterior intestine, anterior digestive gland, and the stomach. It has a depressed ovoidal form and is milky white in color. It is dorsally attached to the fertilization complex, and the proximal portion of the ovospermial duct. It represents about $1 / 4$ of the entire length of the reproductive system (3.53 mm).

The ovospermial duct is broadly embedded in the albumin gland. Its posterior portion shows a groove which originates at the fertilization complex. This is comparatively wide and located between the albumin gland and the prostatic gland, with a total length of $3.92 \mathrm{~mm}$ (more than $1 / 3$ the total length of the reproductive system). It is $1.25 \mathrm{~mm}$ in proximal diameter, and $0.62 \mathrm{~mm}$ in distal diameter and is whitish and semi-transparent. On the latero-ventral portion of this duct can be seen a compressed structure which branches into diverse claviform glandular lobules, representing the proximal prostatic gland. The lobules are similarly sized, and inserted into the posterior (distal) portion of the prostatic gland. On the internal side, the spermatic groove arises from the fertilization complex, running across the laterodorsal part of the of the ovospermial duct, under the prostatic gland, to the level of the vas deferens, where it departs abruptly to attach to the vas deferens. At the level of formation of the vas deferens, the oviducal canal enters the oviduct.

The prostatic gland is divided into proximal and distal portions. The proximal portion is composed of numerous claviform lobules which are acinose, and all of similar size.

The acini of the proximal lobules are more reduced and less differentiated than those of the distal portion. The gland is ovalate, and the ventral face is depressed and its latero-dorsal face is adherent to the ovispermal duct, and a little convex in its dorsal face It is longer than wide and somewhat less in length $(1.57 \mathrm{~mm})$ than the albumin gland, reaching about $1 / 8$ the length of the entire reproductive system. Its maximum length can reach $3.35 \mathrm{~mm}$. Its acini are as small as those of the ovotestis, although somewhat different, and confer a granular appearance to the surface of the structure. The oviduct is long $(2.67 \mathrm{~mm})$ and has almost the same diameter (1.10) as the ovispermial duct. It extends from the region near the origin of the vas deferens, and continues from the ovispermial duct to the vaginal zone, next to the regions of the formation of the phallus sheath and the duct of the copulatory bursa. Its aspect is similar to that of the ovispermial duct, and is velvety and with no visible groove. The duct of the copulatory bursa is thin, $0.70 \mathrm{~mm}$ in diameter, and elongated $(3.31 \mathrm{~mm})$, representing about $1 / 4$ of the length of the entire reproductive 
system. It runs from the dorsolateral stage of the prostatic gland to the distal stage of the albumin gland, into which it inserts to the left of the copulatory bursa. The bursa is whitish, digitiform, narrow $(0.86 \mathrm{~mm})$ and somewhat elongated $(1.89 \mathrm{~mm})$. The vagina is short $(0.78 \mathrm{~mm})$, is almost $1 / 16$ the entire length of the reproductive system, and is somewhat smaller in diameter $(0.47 \mathrm{~mm})$ than the oviduct.

It is whitish and semitransparent, and lies between the genital atrium and region of origin of the duct of the copulatory bursa, continuing to the oviduct.

The vas deferens is $0.06 \mathrm{~mm}$ in width and $6.67 \mathrm{~mm}$ in length, representing about $1 / 2$ the length of the entire reproductive system. It is whitish and semitransparent in color. The proximal portion originates ventrally between the ovispermial duct and the oviduct, where it continues internally along the spermatic groove. The distal portion continues from the proximal portion of the epiphallus, surrounding the vagina and becoming attached to the region of the atrium by a very fine commissure.

The epiphallus is short in relation to the phallus, representing $70 \%$ of its length $(2.67 \mathrm{~mm})$, also being thinner $(0.63 \mathrm{~mm})$ than the phallus. The epiphallus has a dilatation which runs from median to the distal zone, followed by a brusque constriction, then continuing in the vas efferens which is $11 \mathrm{x}$ finer than the epiphallus. The phallian retractor muscle arises next to the proximal extreme of the epiphallus, which is composed of a central, tubular, straight muscle, and another tubular muscle which follows a spiral path around the central muscle. These muscles are united by a thin, translucent layer of connective tissue. The muscles are of similar diameters $(0.31$ $\mathrm{mm}$ ) with the central muscle having a length of 2.36 $\mathrm{mm}$. The proximal portion of the epiphallus provides continuity to the phallus. It is also whitish in color, similar to the phallus, with semitransparent walls. Internally it forms a wide duct, the walls of which are slightly velvety.

The phallus is $3.69 \mathrm{~mm}$ in length (less than $1 / 4$ the length of the entire reproductive system), $0.78 \mathrm{~mm}$ in proximal diameter, and 0.94 in distal diameter. The proximal part continues in the epiphallus, internally posessing a more whitish mass, which is the actual phallus. This is the conoid, having a distal level which is truncated and oblique, within which is found a narrow, elliptical opening. The wide part (distal) represents the phallus sheath, originating in the area of the genital atrium. The internal level of the wall is simple, having an opalescent appearance.

The genital atrium is somewhat more dilated (1.57 $\mathrm{mm}$ ) when compared with the vagina, and is shorter $(2.27 \mathrm{~mm})$, at about $1 / 5$ the vaginal length. Beginning from the vagina, next to the phallic insertion, it opens towards the genital pore. There is also an accesory organ next to the phallus which shows three internal conduits formed of structures resembling piled discs of whitish color, which probably serve as a primary receptor for the allosperms during copulation. The genital pore is $0.63 \mathrm{~mm}$ in diameter, and is very small in relation to the genital atrium. It opens to the lateral zone in the cephalic region, close to the base of the right ommatophore, somewhat below the pneumostome.

\section{DISCUSSION}

Flammulina festiva has diurnal habits, and is generally found under ground-level vegetation probably due to its requirement for humid habitat (Cook 2001). It has a pallial complex composed of a triangular kidney which is partially bisected by the primary ureter (bilobed kidney) as found in Flammulina zebra (Le Guillou 1842), Amphidoxa marmorella (Pfeiffer 1845), Stephanoda binneyana (Pfeiffer 1847), Radiodiscus millecostatus (Pilsbry $\&$ Ferris 1906) and as generally described for the family Charopidae (Pilsbry 1948, Solem 1983). The kidney opens to an excretory duct through a ureter which is relatively long and divided into primary and secondary portions. Similarly to F. zebra, $S$. binneyana and $R$. millecostatus. A. marmorella, $F$. festiva lacks a secondary ureter (Pilsbry 1948, Solem 1983).

Flammulina festiva is a syntrematic species (common genital opening for both male and female tracts), with a reproductive system characteristically semidiaulic (Tompa 1984, Nordsieck 1985). The penis is euphallic (Tompa 1984). The characteristics of the hermaphrodite duct, albumin gland, spermatheca, prostate, uterus, vas deferens, phallus, epiphallus, penile retracto muscle, vagina and atrium in this species fit previous descriptions of the same structures in the family Charopidae (Pilsbry 1948, Solem 1983, Fonseca 1994). The hermaphroditic gonad (ovotestis), covered by a fine epithelium, is located in the middle of the digestive gland and composed of seven lobules connected by a membrane. 


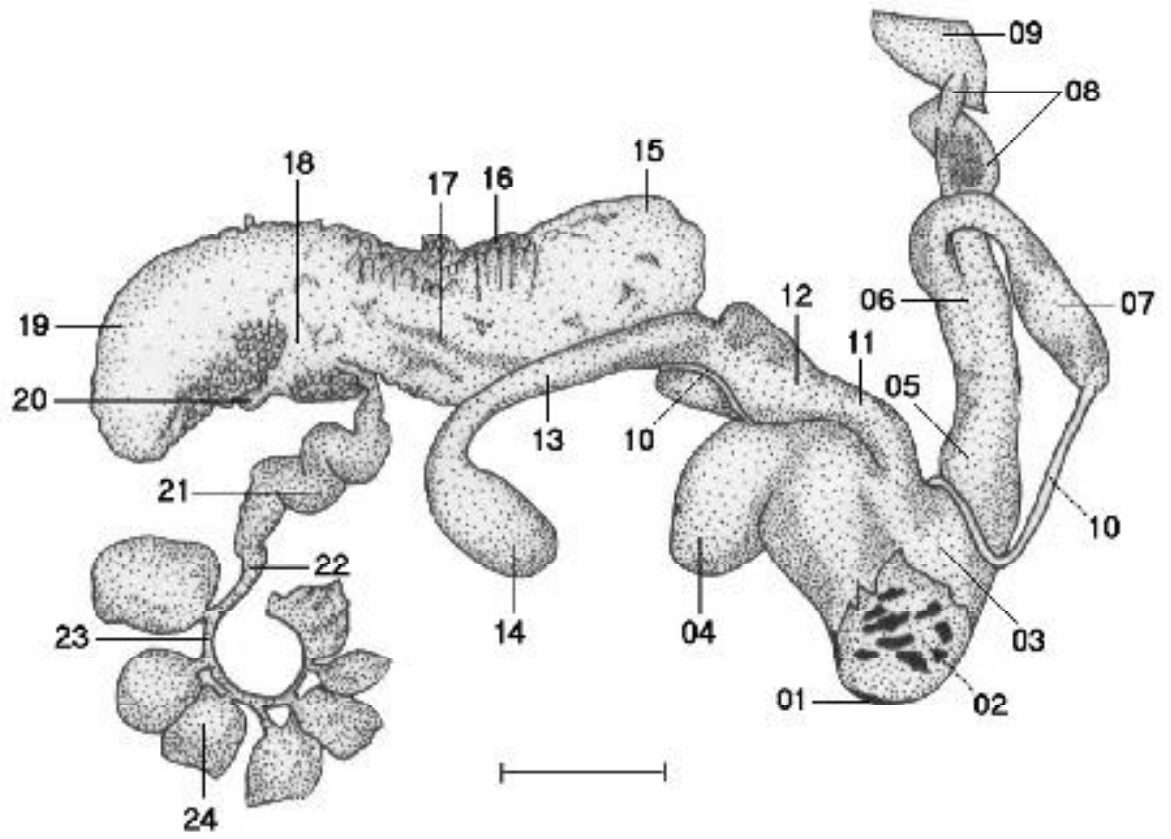

FIGURE 4. Reproductive system of Flammulina festiva. 01: genital aperture, 02: external tissue next to (01), 03: genital atrium, 04: accessory organ, 05 : phallic sheath, 06: phallus, 07: epiphallus, 08: phallic retractor muscles, 09: piece of supporting tissue, 10: vas deferens, 11: vagina, 12: oviduct, 13: copulatory bursa duct, 14: copulatory bursa 15: prostatic gland, 16: diverticulated prostatic gland, 17: spermatic groove, 18: fertilization complex, 19: albumin gland, 20: fertilization sac, 21: seminal vesicle, 22: ovospermial duct, 23: vas efferens of ovotestis, 24: third lobe of ovotestis (distal-apical). Scale: $2 \mathrm{~mm}$.

FIGURA 4. Sistema reproductor de Flammulina festiva. 01: apertura genital, 02: tejido externo adyacente a (01), 03: atrio genital, 04: órgano accesorio, 05: vaina fálica, 06: falo, 07: epifalo, 08: músculo retractor del falo, 09: tejido de soporte, 10: vaso deferente, 11: vagina, 12: oviducto, 13: ducto de la bursa copulatriz, 14: bursa copulatriz, 15: glándula prostática, 16: glándula prostática diverticulada, 17: surco espermático, 18: complejo de fertilización, 19: glándula del albumen, 20: saco de fertilización, 21: vesícula seminal, 22: ducto ovoespermático, 23: vaso eferente del ovotestis, 24: tercer lóbulo del ovotestis (distal-apical). Escala: $2 \mathrm{~mm}$.

It is primarily this characteristic (ovotestis divided into seven lobes) that differentiates this species from F. zebra, R. millecostatus (with two lobes) and from A. marmorella (ovotestis divided into three lobes). In contrast, $S$. binneyana, has a gonadal configuration similar to that of $F$. festiva, but with the ovotestis divided into eight lobes.

The characteristics of the excretory/reproductive system of $F$. festiva support its inclusion in the family Charopidae. However, the morphology show by $F$. festiva is quite different from that described for Flammulina, particularly in relation to its reproductive system. Therefore, probably a new genus needs to be established for $F$. festiva.

Future studies need to elucidate the anatomies of the many other species of terrestrial Chilean gastropods to help establish, at least on a broad scale, the phylogenetic and evolutionary affinities of this Molluscan fauna.

\section{ACKNOWLEDGMENTS}

We thank to the administrative staff of the Valdivian Coastal Reserve (The Nature Conservancy) for facilities provided at the field studies. Also thanks are due to $S$. Miquel and B. Hausdorf for their critical review of the early version of manuscript. Research and publications costs were partially supported by a research grant (DID-UACH S 2005-12) to C.S. Gallardo. 


\section{BIBLIOGRAPHY}

Соок, А. 2001. Behavioural Ecology. In: The Biology of Terrestrial Molluscs (Ed. Barker, G.), pp. 447488. CABI Publishing, Wallingford.

Duncan, C.J. 1975. Reproduction. In: Pulmonates. Vol. 1. Functional anatomy and physiology (Eds. Fretter, V. \& J. Peake), pp. 309-365. Academic Press, London.

FonseCA, A.L. 1994. Conquiliomorfología y anatomía de los sistemas excretor y reproductor de Radiodiscus thomei Weyrauch, 1965. Biociencias 2: 163-188.

KusChEL, G. 1960. Terrestrial zoology in southern Chile. Proceedings of the Royal Society of London. Series B, Biological Sciences 152: 540-550.

Nordsieck, H. 1985. The system of Stylommatophora (Gastropoda), with special regard to the systematic position of the Clausiliidae. Archiv fuer Molluskenkunde 166: 1-24.

Pilsbry, H. 1948. Land Mollusca of North America (north of Mexico). Monograph 3. Academy of Natural Sciences of Philadelphia. 1113 pp.
Sсотт, M.I. 1970. Endodontidos de la región austral americana. Revista del Museo Argentino de Ciencias Naturales "Bernardino Rivadavia" 10 266-296.

Solem, A. 1976. Endodontoid land snails from Pacific Islands (Mollusca: Pulmonata: Sigmurethra). Part I. Family Endodontidae. Field Museum of Natural History, Chicago. 508 pp.

Solem, A. 1983. Endodontoid land snail from Pacific Islands (Mollusca: Pulmonata: Sigmurethra). Part II: Families Punctidae and Charopidae, Zoogeography. Fiel Museum of Natural History, Chicago. 336 pp.

Stuardo, J. \& R. Vega. 1985. Synopsis of the land Mollusca of Chile with remarks on distribution. Studies on Neotropical Fauna and Environment 20: $125-124$.

Tомға, A.S. 1984. Land Snails (Stylommatophora). In: The Mollusca (Eds. Tompa, A., N. Verdonk \& J. Van Den Biggelaar), pp. 47-140. Academic Press, Orlando.

VAlDovinos, C. 1999. Biodiversidad de moluscos chilenos: Base de datos taxonómica y distribucional. Gayana 63: $111-164$ 